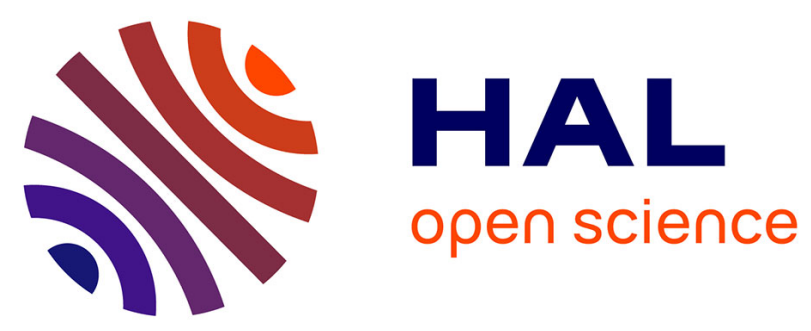

\title{
Cadmium Hyperaccumulation and Reproductive Traits in Natural Thlaspi caerulescens Populations
}

\author{
Nevena Basic, Catherine Keller, Pierre Fontanillas, Pascal P. Vittoz, \\ Guillaume Besnard, Nicole Galland
}

\section{- To cite this version:}

Nevena Basic, Catherine Keller, Pierre Fontanillas, Pascal P. Vittoz, Guillaume Besnard, et al.. Cadmium Hyperaccumulation and Reproductive Traits in Natural Thlaspi caerulescens Populations. Plant Biology, 2006, 8 (1), pp.64-72. 10.1055/s-2005-872892 . hal-01494197

\section{HAL Id: hal-01494197 \\ https://hal-amu.archives-ouvertes.fr/hal-01494197}

Submitted on 6 Apr 2017

HAL is a multi-disciplinary open access archive for the deposit and dissemination of scientific research documents, whether they are published or not. The documents may come from teaching and research institutions in France or abroad, or from public or private research centers.
L'archive ouverte pluridisciplinaire HAL, est destinée au dépôt et à la diffusion de documents scientifiques de niveau recherche, publiés ou non, émanant des établissements d'enseignement et de recherche français ou étrangers, des laboratoires publics ou privés. 


\title{
Cadmium Hyperaccumulation and Reproductive Traits in Natural Thlaspi caerulescens Populations
}

\author{
N. Basic ${ }^{1}$, C. Keller ${ }^{2,3}$, P. Fontanillas ${ }^{4}$, P. Vittoz ${ }^{1}$, G. Besnard ${ }^{1}$, and N. Galland ${ }^{1}$ \\ ${ }^{1}$ Department of Ecology and Evolution, University of Lausanne, Biology Building, 1015 Lausanne, Switzerland \\ ${ }^{2}$ ENAC-ISTE-Laboratory of Soil Science, Swiss Federal Institute of Technology, 1015 Lausanne, Switzerland \\ 3 Present address: CEREGE, Europôle Méditerranéen de l'Arbois, Université Aix-Marseille III, BP 80, 13545 Aix-en-Provence, Cedex 4, France \\ ${ }^{4}$ Department of Organismic and Evolutionary Biology, Harvard University, Cambridge, MA 02138, USA
}

Received: March 24, 2005; Accepted: August 31, 2005

\begin{abstract}
During the last decade, the metal hyperaccumulating plants have attracted considerable attention because of their potential use in decontamination of heavy metal contaminated soils. However, in most species, little is known regarding the function, the ecological and the evolutionary significances of hyperaccumulation. In our study, we investigated the parameters influencing the $\mathrm{Cd}$ concentration in plants as well as the biological implications of $\mathrm{Cd}$ hyperaccumulation in nine natural populations of Thlaspi caerulescens. First, we showed that Cd concentration in the plant was positively correlated with plant $\mathrm{Zn}, \mathrm{Fe}$, and $\mathrm{Cu}$ concentrations. This suggested that the physiological and/or molecular mechanisms for uptake, transport and/or accumulation of these four heavy metals interact with each other. Second, we specified a measure of Cd hyperaccumulation capacity by populations and showed that $T$. caerulescens plants originating from populations with high Cd hyperaccumulation capacity had better growth, by developing more and bigger leaves, taller stems, and produced more fruits and heavier seeds. These results suggest a tolerance/disposal role of Cd hyperaccumulation in this species.
\end{abstract}

Key words: Cadmium (Cd), hyperaccumulation capacity, reproductive traits, shoot traits, Thlaspi caerulescens, tolerance.

\section{Introduction}

Cadmium (Cd) is a widespread heavy metal released into the environment by anthropogenic activities and is a source of serious environmental and health hazards. Particularly, its presence in the soil is problematic for all organisms as it will be taken up by plants and accumulated along the food chain (Sanita di Toppi and Gabbrielli, 1999). In recent years, the reclamation of metal contaminated soils through remediation measures has attracted considerable attention. In this context, hyperaccumulator plants can be used for phytoremediation of heavy metal polluted soils, as they are able to extract and concentrate metals in their upper parts that can be harvested (Chaney, 1983; Brooks, 1998). Numerous studies have focused

Plant Biol. 8 (2006): 64-72

(c) Georg Thieme Verlag KG Stuttgart · New York DOI 10.1055/s-2005-872892 • Published online November 8, 2005 ISSN 1435-8603 on the identification of hyperaccumulator plants and their growth, tolerance, and hyperaccumulation on highly contaminated soils (Baker et al., 1994; Assunção et al., 2003; Roosens et al., 2003). Few have focused on soils with naturally occurring elements (Meerts and Van Isacker, 1997; Escarré et al., 2000; Molitor et al., 2005). These soils can present a large range of metal concentrations, low as well as high (in serpentine soils). Many heavy metals, like $\mathrm{Zn}$ and $\mathrm{Cu}$, have physiological functions in plants but become toxic at high concentrations (Blaylock and Huang, 2000). Others, such as $\mathrm{Pb}$ and $\mathrm{Cd}$, are toxic to plants even in small amounts (Shaw et al., 2004).

The genetic basis, the physiological pathways - in particular for $\mathrm{Cd}$ - and the adaptive significance of metal hyperaccumulation are not yet well understood (Pollard et al., 2002; Roosens et al., 2003). Four main hypotheses have been postulated to explain the function of metal hyperaccumulation: 1) drought hypothesis, 2) interference hypothesis, 3) defence hypothesis, and 4) tolerance/disposal hypothesis (Boyd, 2004). The first hypothesis states that hyperaccumulated metal may help hyperaccumulators withstand drought by reducing cuticular transpiration (Severne, 1974) or by increasing osmolarity within the cell (Baker and Walker, 1989). Indeed, many hyperaccumulator species can be found in arid Mediterranean climates and/or on soils with negative water potential (Whiting et al., 2003). However, facts bearing on this hypothesis are scarce and Whiting et al. (2003) found no evidence that hyperaccumulation provide increased drought resistance. The second hypothesis proposes that perennial hyperaccumulator plants enrich the surface soil under their canopies by producing litter high in metals to prevent establishment of less metal tolerant plants (e.g., Baker and Brooks, 1989; Wilson and Agnew, 1992). Although Boyd and Jaffré (2002) showed that concentrations of metals in the surface soils are high under canopies of a long-lived hyperaccumulator tree species, this hypothesis remains untested. The defence hypothesis suggests that elevated metal concentrations in plant tissues protect hyperaccumulators from certain herbivores or pathogens. This hypothesis has attracted a lot of attention. Recently, Noret et al. (2005) showed that foliar $\mathrm{Zn}$ and $\mathrm{Cd}$ concentrations did not affect the feeding choices of snails (Helix aspersa). However, there was some evidence that Cd hyperaccumulation deters thrips (Frankliniella occidentalis) from feeding on plant leaves (Jiang et al., 2005). The tolerance/disposal hypothesis suggests that hyperaccumulation is a mechanism for increased tolerance that allows sequestration of metals in tissues (tolerance) or 
their elimination from the plant body by shedding (disposal) (e.g., Antonovics et al., 1971; Baker, 1981). The mechanism of hyperaccumulation would enable plants to tolerate metals through internal detoxification. There is little evidence linking hyperaccumulation with metal tolerance/disposal (Jiang et al., 2005). However, in controlled conditions, Roosens et al. (2003) and Cosio (2004) have found a decrease in hyperaccumulator biomass production with increasing $\mathrm{Cd}$ concentrations in solution and shoots.

Thlaspi caerulescens J. and C. Presl (Brassicaceae) is a facultative metallophyte of Central and Western Europe that grows on soils with a large range of $\mathrm{Zn}$ and $\mathrm{Cd}$ concentrations (Reeves and Brooks, 1983). It is known to have large variations in metal hyperaccumulation capacity among populations (Baker et al., 1994; Zhao et al., 2003), but the biology of natural populations remains poorly explored. In particular, the role and the evolutionary significance of $\mathrm{Cd}$ hyperaccumulation in this species are largely unknown. Jiang et al. (2005) have provided some evidence for a protective role of Cd hyperaccumulation in $T$. caerulescens against feeding damage by a generalist herbivore. On the other hand, the effects of Cd hyperaccumulation on reproductive traits have never been measured, either in natural populations or under controlled conditions.

The aim of this study was to determine the relationship between Cd hyperaccumulation and reproductive/vegetative traits in natural populations of T. caerulescens. We analysed Cd hyperaccumulation in nine Swiss Jura populations of $T$. caerulescens, covering a broad range of heavy metal concentrations of natural geogenic origin (Atteia et al., 1995; Liebig and Dubois, 1997; Benitez, 1999). First, we determined the parameters influencing the plant $\mathrm{Cd}$ concentration within populations. The parameters investigated, $\mathrm{Cd}, \mathrm{Zn}, \mathrm{Pb}$, and $\mathrm{Cu}$ soil concentrations, $\mathrm{pH}$, heavy metals concentrations in plants (here $\mathrm{Zn}, \mathrm{Fe}, \mathrm{Cu}$, and $\mathrm{Pb}$ ), environmental parameters (direct solar radiation, days of frost, topographic wetness index), and population parameters, such as size and density (intraspecific competition), are known as putatively to affect $\mathrm{Cd}$ concentration in plants (Zhao et al., 2003; Evangelou et al., 2004) and/or are likely to influence plant functioning. Second, we specified a measure of Cd hyperaccumulation capacity and analysed its relationship with reproductive and shoot traits.

\section{Materials and Methods}

\section{Site description and characterisation of populations}

The selection of sites for sampling was based on the distribution map of T. caerulescens in Switzerland (Welten and Sutter, 1982). This work focused on nine Swiss Jura populations (coded for further convenience as J1 to J3, J8 to J11, and J14 to J15). $\mathrm{J} 1$ is located near "St. Cergues", J2 and J3 on the "Col du Marchairuz", J8 and J9 near "Ste. Croix", J10 and J11 on the "Chasseron", and J14 and J15 on "Mont d'Amin". All populations are located between 1100 and $1450 \mathrm{~m}$ (Table 1). They are discontinuous and isolated by forests or ridges. Thlaspi caerulescens, an early flowering plant, grows in the Jura in meadows and mesotrophic pastures characterised by small size species. It is found mainly on stony soils and rocky outcrops. Based on the geotechnical map (GT-CH, OFS GEOSTAT, 1993), all the Jura populations are on limestone with marl deposits, except for J11, which is on a schist and marl substratum.

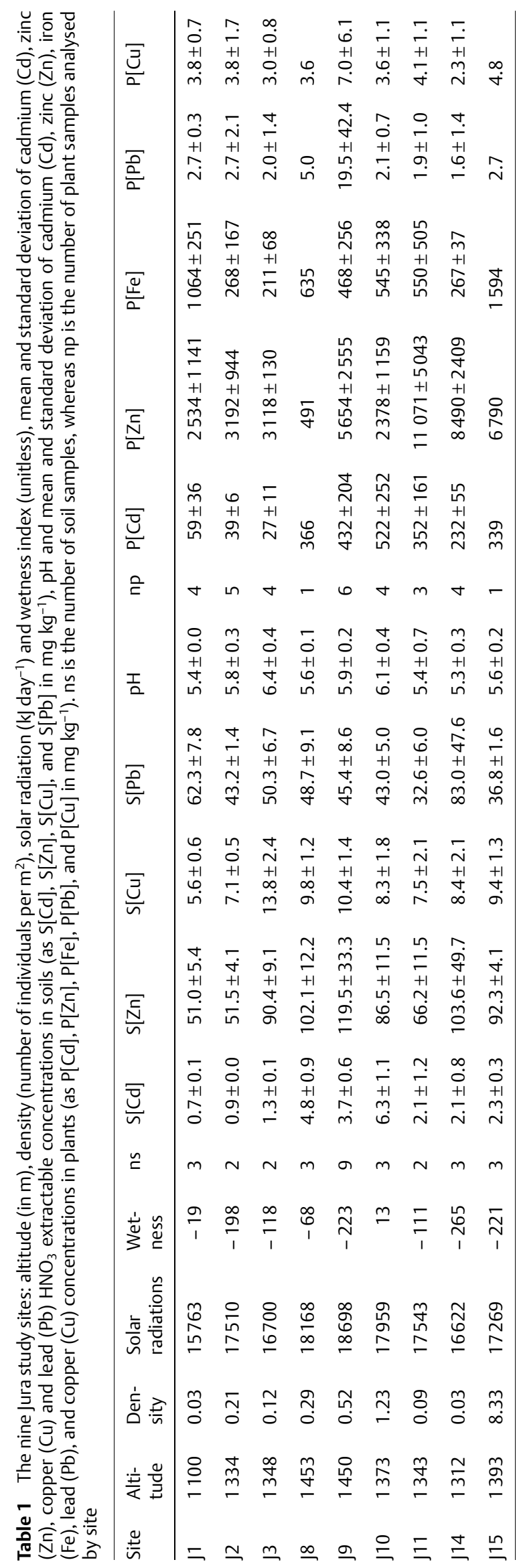


The topographic wetness index, the monthly potential direct shortwave radiation (solar radiation), and the number of frost days during the growing season were spatially extrapolated (Zimmermann and Kienast, 1999) from climatic data (Swiss Federal Institute for Forest, Snow and Landscape Research [WSL]) for each site. The topographic wetness index is a measure of the wetness of a given site, taking into account the drainage of the surrounding area, weighted by its slope (the steeper the slope, the more of the incoming water just passes through and does not remain). The monthly potential direct shortwave radiation represents direct clear sky shortwave radiation in a site, taking into account overshadowing by high peaks.

The population density was estimated in the field (June). It is the ratio between the population size obtained by counting the flowering individuals per population at the same development stages (late raceme flowering) and the population growing area (in $\mathrm{m}^{2}$ ).

\section{$\mathrm{pH}$, metal concentrations in soils}

The analysis of $\mathrm{Cd}, \mathrm{Zn}, \mathrm{Cu}$, and $\mathrm{Pb}$ concentrations in the soil (S[Cd], S[Zn], S[Cu], and S[Pb], respectively) was performed on two to nine soil samples per site, randomly collected in the habitat and near $T$. caerulescens roots, to a maximal root depth of $25 \mathrm{~cm}$. The first $5 \mathrm{~cm}$ of the upper layer were not sampled (root mat). Soils were dried at room temperature, then ground and sieved to $2 \mathrm{~mm}$ mesh size. Soil $\mathrm{pH}$ was measured in $0.01 \mathrm{M}$ $\mathrm{CaCl}_{2}$ (soil/solution 1/2.5) after shaking for $1 \mathrm{~h}$ (FAL, 1998). Soil samples were analysed for $\mathrm{Cd}, \mathrm{Zn}, \mathrm{Cu}$, and $\mathrm{Pb}$ contents using the $2 \mathrm{M} \mathrm{HNO}_{3}$ extraction method (OIS, 1998). This method provides the pseudo-total metal concentrations. $\mathrm{HNO}_{3}$ extractable and plant available Cd concentrations, as defined by $0.1 \mathrm{M}$ $\mathrm{NaNO}_{3}$ extraction (FAC, 1989), have been found to be correlated when compared on the basis of a large dataset (25 populations) $(r=0.66, p<0.001)$. A similar trend was observed for the nine studied populations (data not shown). $\mathrm{NaNO}_{3}$ extractable Zn concentrations were hardly detectable, probably due to the generally low pseudo-total $\mathrm{Zn}$ concentrations and high $\mathrm{pH}$ in Jura soils. $\mathrm{HNO}_{3}$ extractable $\mathrm{Cd}, \mathrm{Zn}, \mathrm{Cu}$, and $\mathrm{Pb}$ concentrations were determined by Inductively Coupled Plasma Atomic Emission Spectrometry (ICP-AES, Perkin Elmer Plasma 2000, Wellesley, USA). Blanks and reference material (W 921) were included in each batch of analysis.

\section{Metal concentrations in plants}

To quantify $\mathrm{Cd}, \mathrm{Zn}, \mathrm{Fe}, \mathrm{Cu}$, and $\mathrm{Pb}$ concentrations in plants ( $\mathrm{P}[\mathrm{Cd}], \mathrm{P}[\mathrm{Zn}], \mathrm{P}[\mathrm{Fe}], \mathrm{P}[\mathrm{Cu}]$, and $\mathrm{P}[\mathrm{Pb}]$, respectively), T. caerulescens leaves were harvested in the field, on one to six plant samples randomly dispersed on the site, cleaned and air-dried at room temperature. Between 20 and $250 \mathrm{mg}$ of dry plant material, representing the total plant shoot biomass, were hand crushed. Sample digestion was performed according to Keller et al. (2003). Heavy metal concentrations in plant extracts were determined by ICP-AES (Perkin Elmer Plasma 2000, Wellesley, USA). Blanks and in house plant reference material were included in each digestion batch. The results were used for calculation of the $\mathrm{Cd}$ hyperaccumulation capacity of populations (see "Results").

\section{Shoot and reproductive traits}

The same development stage for populations and individuals (early raceme flowering and late fruit maturation) was sampled on successive visits to the field. The length of the stem, diameter of the basal leaves, total number of leaves, length of the biggest leaf per individual, and number of flowers were recorded (May to July) on 13 to 20 plants per population. The number of fruits per plant, number of seeds per fruit, and seed weights were determined for six plants per population (July to August). The individuals were randomly selected from each population.

\section{Statistical analyses}

Shoot traits (total number of leaves, length of the stem, diameter of the basal leaves, and length of the biggest leaf per individual) were summarised in two synthetic variables by the two first components of a Principal Component Analysis (PCA) applied on a correlation matrix.

The best linear models for the P[Cd], the two synthetic shoot variables, and the four reproductive traits were selected using three criteria: 1 ) the corrected Akaike's information criterion (AICc) had to be satisfied, 2) the slope of all variables selected had to be significant, and 3) the explained variance of all variables had to be significant. The parameters used as potentially influencing the $\mathrm{P}[\mathrm{Cd}]$ within populations were the topographic wetness index, direct solar radiation, days of frost, population size, and density, pH, S[Cd], S[Zn], S[Cu], S[Pb], P[Zn], P[Fe], $\mathrm{P}[\mathrm{Cu}]$, and $\mathrm{P}[\mathrm{Pb}]$. These parameters, except for $\mathrm{S}[\mathrm{Cu}]$ and $\mathrm{S}[\mathrm{Pb}]$ (see "Results"), and the Cd hyperaccumulation capacity (as defined in the results section) were chosen as potentially influencing shoot traits. The parameters used as potentially influencing the reproductive traits (defined as the weight and number of seeds per fruit, number of fruits per plant, and number of flowers) were the same as those influencing the shoot traits and the shoots traits themselves. To deal with our relatively small number of populations (nine populations) and large number of variables, we used a sampling procedure of variables. All statistical analyses were performed using R 1.7.1 (Ihaka and Gentleman, 1996).

\section{Results}

\section{Parameters related to $C d$ concentration in plants}

$\mathrm{HNO}_{3}$ extractable $\mathrm{Cd}$ concentration in soils ( $\mathrm{S}[\mathrm{Cd}]$ ) varied between $0.7 \mathrm{mg} \mathrm{kg}^{-1}$ up to a maximum of $6.3 \mathrm{mg} \mathrm{kg}^{-1}$, whereas its concentration in plants ( $\mathrm{P}[\mathrm{Cd}])$ was between 27 and $522 \mathrm{mg}$ $\mathrm{kg}^{-1}$ (Table 1). The results for the other metal concentrations in soils and plants are given in Table $\mathbf{1}$.

$\mathrm{P}[\mathrm{Cd}]$ was positively correlated to $\mathrm{S}[\mathrm{Cd}]$ ( slope $=92.64, \mathrm{t}=31.2$, $p<0.001$ ), to $\mathrm{P}[\mathrm{Zn}]$ (slope $=0.024, \mathrm{t}=12.8, p<0.001$ ), $\mathrm{P}[\mathrm{Fe}]$ (slope $=0.063, \mathrm{t}=5.2, p<0.01)$, and $\mathrm{P}[\mathrm{Cu}]($ slope $=22.44, \mathrm{t}=5.3$, $p<0.01$ ) (Table 2). This model explains $99.4 \%$ of the variance, with S[Cd] alone explaining $75.1 \%$ (Fig. 1 A).

\section{Cd hyperaccumulation capacity}

In the nine populations, $\mathrm{P}[\mathrm{Cd}]$ was completely explained by $\mathrm{S}[\mathrm{Cd}]$ and intrinsic parameters $(\mathrm{P}[\mathrm{Zn}], \mathrm{P}[\mathrm{Fe}]$ and $\mathrm{P}[\mathrm{Cu}])$ : the residuals of the regression between $\mathrm{P}[\mathrm{Cd}]$ and $\mathrm{S}[\mathrm{Cd}]$ are thus a 
Table 2 Best linear model for the Cd concentration in plants (P[Cd]), the first (PCA 1) and the second (PCA 2) shoot trait, the number of flowers and fruits, number of seeds per fruit, and seed weight

\begin{tabular}{|c|c|c|c|}
\hline & Estimate & t value & $p$-value \\
\hline \multicolumn{4}{|l|}{$P[C d]\left(R^{2}=99.4 \%\right)$} \\
\hline$S[C d]$ & 92.46 & 23.9 & $* * *$ \\
\hline $\mathrm{P}[\mathrm{Zn}]$ & 0.023 & 11.2 & $* * *$ \\
\hline $\mathrm{P}[\mathrm{Fe}]$ & 0.086 & 5.7 & $* *$ \\
\hline $\mathrm{P}[\mathrm{Cu}]$ & 22.44 & 5.3 & $* *$ \\
\hline \multicolumn{4}{|l|}{ Shoot trait PCA1 $\left(R^{2}=93.4 \%\right)$} \\
\hline Wetness index & 0.015 & -9.5 & $* * *$ \\
\hline Solar radiations & -0.0006 & 3.9 & * \\
\hline Cd hyperaccumulation capacity & 0.012 & -7.3 & $* * *$ \\
\hline \multicolumn{4}{|l|}{ Shoot trait PCA2 $\left(R^{2}=65.6 \%\right)$} \\
\hline$S[Z n]$ & 0.037 & 4.0 & $* *$ \\
\hline \multicolumn{4}{|l|}{ Number of flowers $\left(R^{2}=98.9 \%\right)$} \\
\hline Solar radiations & -0.0074 & -11.5 & $* *$ \\
\hline Density & -1.70 & -12.2 & $* *$ \\
\hline $\mathrm{S}[\mathrm{Cd}]$ & 1.20 & 3.2 & $*$ \\
\hline $\mathrm{P}[\mathrm{Pb}]$ & 0.61 & 8.2 & $* *$ \\
\hline$P[C d]$ & -0.039 & -9.4 & $* *$ \\
\hline \multicolumn{4}{|l|}{ Number of fruits ( $\left.R^{2}=95.7 \%\right)$} \\
\hline Solar radiations & -0.012 & -12.2 & $* * *$ \\
\hline $\mathrm{P}[\mathrm{Fe}]$ & -0.013 & -7.4 & $* *$ \\
\hline $\mathrm{P}[\mathrm{Pb}]$ & 1.31 & 8.3 & $* *$ \\
\hline Cd hyperaccumulation capacity & 0.03 & 3.2 & * \\
\hline \multicolumn{4}{|c|}{ Number of seeds per fruit $\left(R^{2}=99.2 \%\right)$} \\
\hline Density & -0.21 & -13.1 & $* * *$ \\
\hline Biomass PCA1 & 0.23 & -7.6 & $* *$ \\
\hline Biomass PCA2 & 0.81 & 19.0 & $* * *$ \\
\hline $\mathrm{P}[\mathrm{Pb}]$ & -0.11 & -13.5 & $* * *$ \\
\hline $\mathrm{P}[\mathrm{Zn}]$ & 0.053 & 4.2 & * \\
\hline \multicolumn{4}{|l|}{ Seed weight $\left(R^{2}=40.9 \%\right)$} \\
\hline Cd hyperaccumulation capacity & 0.0004 & 2.6 & * \\
\hline
\end{tabular}

${ }^{*} p<0.05 ;{ }^{* *} p<0.01 ;{ }^{* * *} p<0.001$

feature of plants themselves, and not of the environment, in each of the nine populations. We called these residuals " $\mathrm{Cd}$ hyperaccumulation capacity" because they quantify the hyperaccumulation differences among populations (Figs. 1 A,B). Note that $\mathrm{P}[\mathrm{Cd}]$ was not correlated with the other metal concentrations in the soils (S[Zn], S[Pb], and S[Cu]).

$\mathrm{P}[\mathrm{Zn}]$ was not correlated either with $\mathrm{S}[\mathrm{Zn}]$ (slope $=0.00043$, $\mathrm{t}=0.2, p=0.88), \mathrm{S}[\mathrm{Cd}]$ (slope $=-488.6, \mathrm{t}=-0.7, p=0.48), \mathrm{S}[\mathrm{Pb}]$ (slope $=-6.63, \mathrm{t}=-0.08, p=0.94$ ), or with $\mathrm{S}[\mathrm{Cu}]$ (slope $=$ $-196.6, \mathrm{t}=-0.4, p=0.73$ ) alone. It was related to $\mathrm{P}[\mathrm{Cd}]$ (slope $=$ 43.8, $\mathrm{t}=13.8, p<0.001), \mathrm{P}[\mathrm{Fe}]($ slope $=-2.8, \mathrm{t}=-4.8, p<0.01)$, and $\mathrm{P}[\mathrm{Cu}]$ (slope $=-974.7, \mathrm{t}=-4.6, p<0.01$ ), once the effect of $\mathrm{S}[\mathrm{Cd}]$ ( slope $=-4069.2, \mathrm{t}=-14.3, p<0.001$ ) was removed from the linear regression. This model explained $96.3 \%$ of the variance of $\mathrm{P}[\mathrm{Zn}] . \mathrm{P}[\mathrm{Cu}]$ and $\mathrm{P}[\mathrm{Pb}]$ did not show any correlation with, respectively, $\mathrm{S}[\mathrm{Cu}]$ ( slope $=0.037, \mathrm{t}=0.2, p=0.87$ ) and $\mathrm{S}[\mathrm{Pb}]$ ( slope $=2.54, \mathrm{t}=1.1, p=0.32)$. There was no correlation between any of the studied metal concentrations in soils. Pseudo-total Fe concentration in soils was not measured in this study because $\mathrm{S}[\mathrm{Fe}]$ does not provide information on either Fe availability or P[Fe] (Marschner, 1995; Molitor et al., 2005). In order to reduce the number of parameters employed in the linear models for the two synthetic shoot variables and the four reproductive traits, $\mathrm{S}[\mathrm{Cu}]$ and $\mathrm{S}[\mathrm{Pb}]$ were not used because of their low concentrations in soils as compared to $S[C d]$ and $S[Z n]$ and because they showed no significant simple linear correlation with the shoot and reproductive traits.

\section{Parameters related to shoot and reproductive traits}

The two first components of the PCA on shoot traits explained $76.8 \%$ of the total variance, with the first one explaining almost $52 \%$. The first component summarised the length of the biggest leaf per individual, the diameter of the basal leaves, and the stem length, whereas the second component of the PCA was related to the total number of leaves per plant (Fig. 2).

The first component of the PCA on shoot traits (PCA 1) was correlated to the wetness index $($ slope $=0.015, t=-9.5, p<0.001)$, to solar radiation (slope $=-0.0006, \mathrm{t}=3.9, p<0.05$ ), and positively to $\mathrm{Cd}$ hyperaccumulation capacity of populations ( lope $=0.012, t=-7.3, p<0.001$ ) (Figs. 2,3A). This model explained $93.4 \%$ of the variance of the first synthetic shoot trait (Table 2). The second PCA component (PCA 2) was correlated to $\mathrm{S}[\mathrm{Zn}]$ ( slope $=0.037, \mathrm{t}=4.0, p<0.01)$. $\mathrm{S}[\mathrm{Zn}]$ explained $65.6 \%$ of the second synthetic shoot trait variance (Table 2 ).

The best model for the number of fruits explained almost all the variance $\left(R^{2}=95.7 \%\right)$. The number of fruits was correlated to the solar radiation ( slope $=-0.012, \mathrm{t}=-12.2, p<0.001$ ), $\mathrm{P}[\mathrm{Fe}]$ (slope $=-0.013, \mathrm{t}=-7.4, p<0.01), \mathrm{P}[\mathrm{Pb}] \quad$ (slope $=1.31$, $\mathrm{t}=8.3, p<0.01$ ), and positively to the Cd hyperaccumulation capacity of populations ( slope $=0.03, t=3.2, p<0.05$ ) (Table 2 , Fig. 3 B). The best model for the seed weight explained $40.9 \%$ of the variance. The seed weight was positively correlated to the Cd hyperaccumulation capacity of populations ( slope $=0.0004$, $\mathrm{t}=2.6, p<0.05$ ) (Table 2, Fig. $\mathbf{3}$ B).

The number of flowers and the number of seeds per fruit were not related to the Cd hyperaccumulation capacity of populations (Table $\mathbf{2}$ ).

\section{Discussion}

The studied populations located on normal or moderately con-

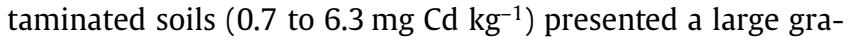
dient of $\mathrm{Cd}$ concentration in plants. Whereas the threshold applied for defining Cd hyperaccumulation is $100 \mathrm{mg} \mathrm{Cd} \mathrm{kg} \mathrm{m}^{-1}$ shoot dry weight (Brown et al., 1994), six out of nine studied populations displayed plant $\mathrm{Cd}$ concentrations of more than $200 \mathrm{mg} \mathrm{kg}^{-1}$, up to a maximum of $522 \mathrm{mg} \mathrm{kg}^{-1}$. Indeed, some of the Swiss populations had an ability to hyperaccumulate Cd comparable to the Southern French populations, highlighted as highly $\mathrm{Cd}$ hyperaccumulating ecotypes (Zhao et al., 2003).

The positive correlation between $\mathrm{Cd}, \mathrm{Fe}, \mathrm{Zn}$, and $\mathrm{Cu}$ plant concentrations suggested that, in the studied populations, $\mathrm{Cd}, \mathrm{Zn}$, $\mathrm{Fe}$, and $\mathrm{Cu}$ uptake, transport and/or accumulation were linked. Zha et al. (2004) had shown that the component(s) of the met- 


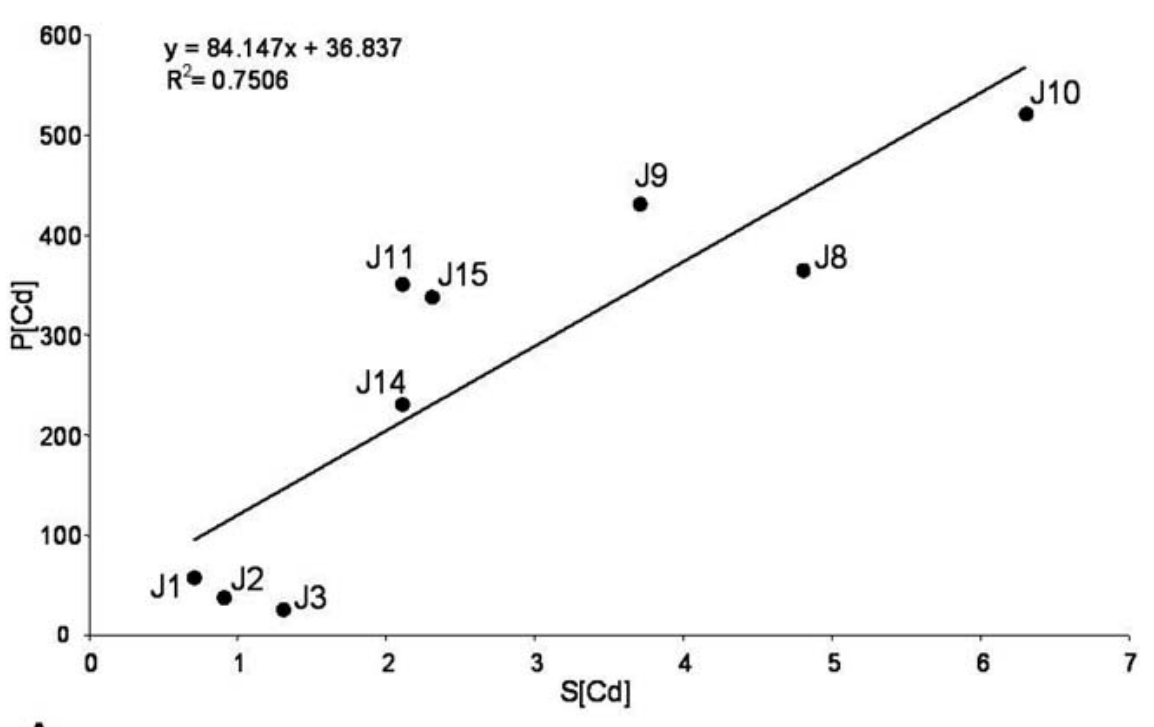

A

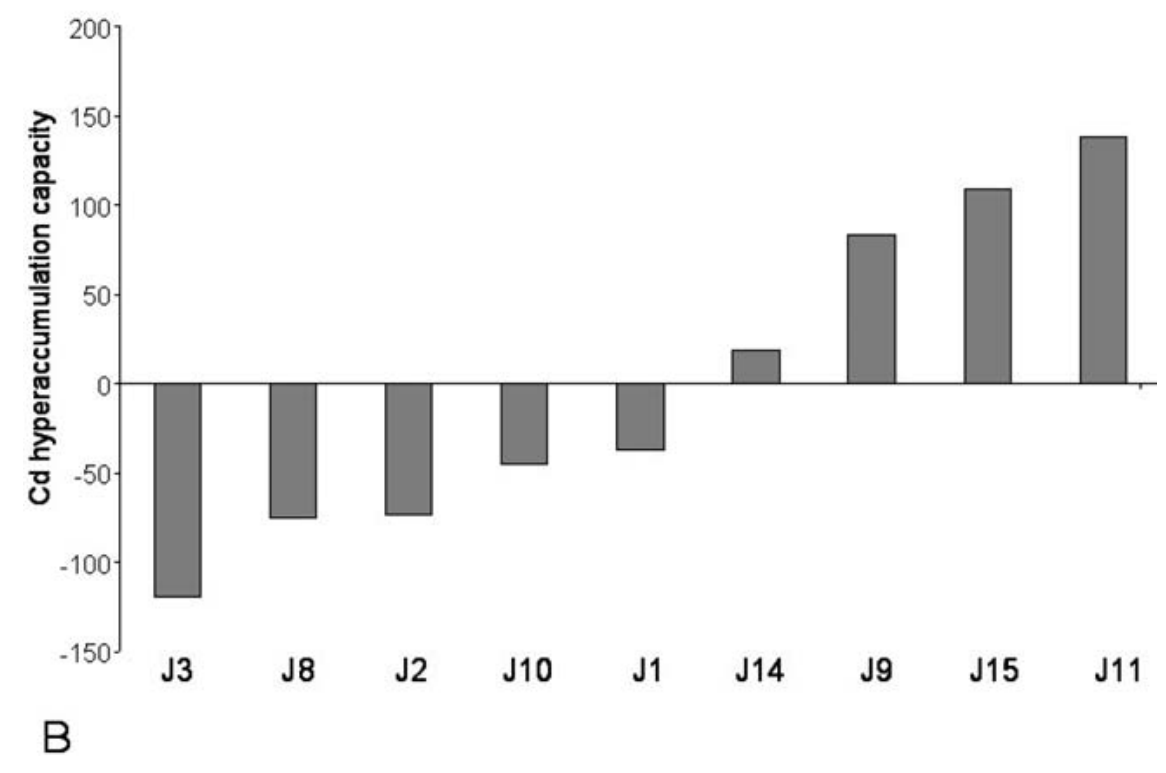

Fig. 1 Linear regression between the cadmium concentrations in plants $(\mathrm{P}[\mathrm{Cd}])$ and $\mathrm{HNO}_{3}$ extractable cadmium concentration in soils (S[Cd]) (in $\mathrm{mg} \mathrm{kg}^{-1}$ ) of the nine Jura study populations $(\mathbf{A})$ and their $\mathrm{Cd}$ hyperaccumulation capacity $(\mathbf{B})$. al transport system in T. caerulescens are able to transport multiple metals. It is often assumed that Cd and other heavy metals without a biological function are taken up by transporters for essential elements because of a lack of specificity (Lombi et al., 2002). It is believed that Cd uptake by non-accumulator plants represents opportunistic transport via cation channels for $\mathrm{Ca}$ and $\mathrm{Mg}$ or via a carrier for other divalent cations such as $\mathrm{Zn}, \mathrm{Cu}$, or Fe (Welch and Norvell, 1999). In the hyperaccumulator T. caerulescens, Cd was proposed to enter the cell via either a high affinity uptake system for Fe (Lombi et al., 2002; Vert et al., 2002) or a low affinity system for Ca or Zn uptake (Baker et al., 1994; Escarré et al., 2000; Roosens et al., 2003; Cosio et al., 2004; Molitor et al., 2005; Zha et al., 2004), depending on the population studied. The differences in Cd uptake found between populations suggested a high affinity transporter for Cd for specific populations (Lombi et al., 2001; Zha et al., 2004). Our results showed that Cd hyperaccumulation mainly depended on soil Cd concentrations, which ex- plained $75 \%$ of plant Cd concentrations, although Cd concentrations in soils were low compared to the serpentinic or metallicolous soils. Again, it must be mentioned here that pseudo-total soil Cd concentration could be used because it was also correlated to plant available $\mathrm{Cd}$, as defined by a $0.1 \mathrm{M}$ $\mathrm{NaNO}_{3}$ extraction. All the residual variance between plant $\mathrm{Cd}$ concentration and soil $\mathrm{Cd}$ concentration was explained by the concentration of other heavy metals in the plant and not by extrinsic (environmental and population) parameters (soil Zn concentration included). This suggested that this residual variance measures an intrinsic variance between populations, which we called Cd hyperaccumulation capacity. In other words, some populations hyperaccumulate more Cd than others, and this $\mathrm{Cd}$ hyperaccumulation is also related to larger $\mathrm{Zn}$, $\mathrm{Fe}$, and $\mathrm{Cu}$ accumulation. 


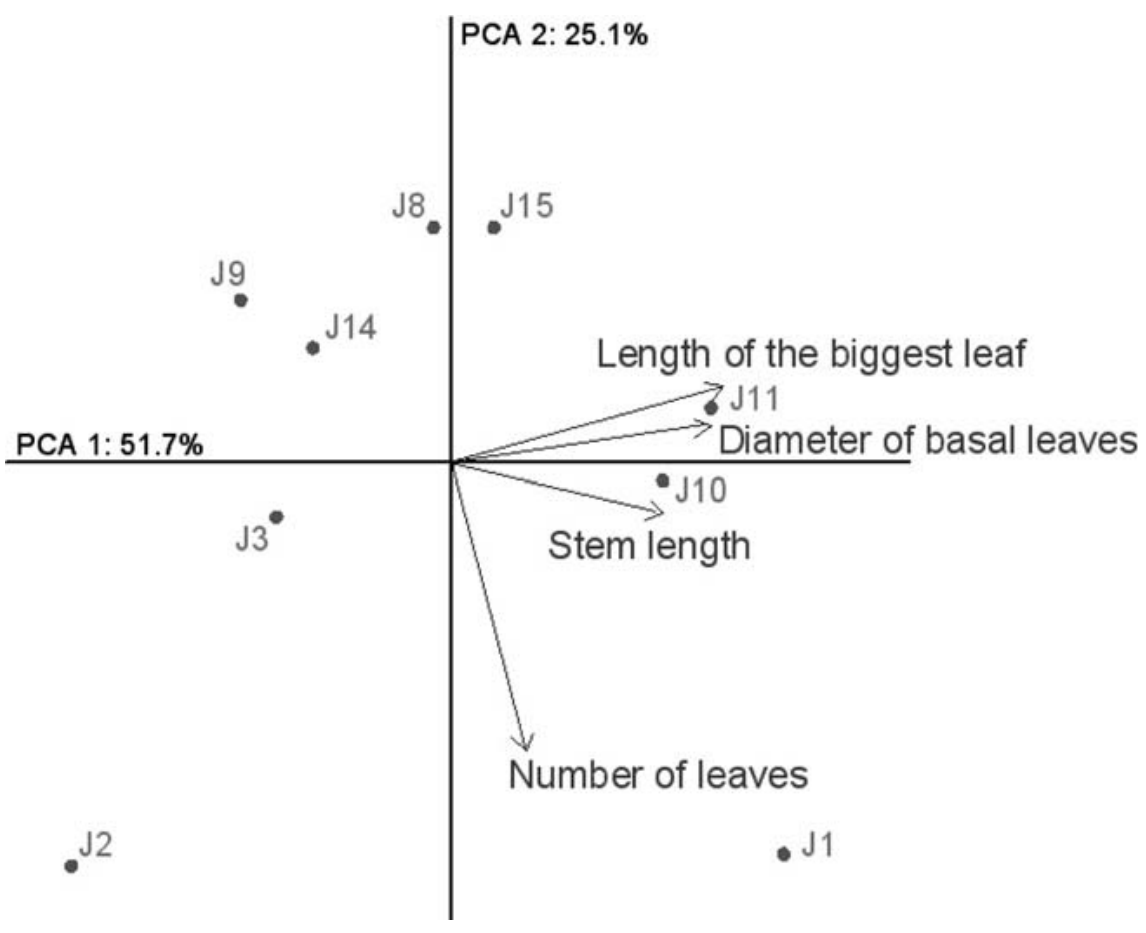

Fig. 2 PCA on shoot traits among nine Thlaspi caerulescens populations and contribution of the total number of leaves, length of the stem, diameter of the basal leaves, and length of the biggest leaf to its first two components (as PCA 1, PCA 2).
The effects of Cd on growth have mostly been investigated in the lab: the aerial biomass was positively correlated to $\mathrm{Cd}$ substrate content in metallicolous populations and negatively in normal populations (Escarré et al., 2000). The shoot traits of our populations were not correlated to $\mathrm{Cd}$ concentrations in soils. On the other hand, the biomass was negatively correlated with Cd content in aerial parts for metallicolous populations, but for normal or nonmetalliferous soils, there is no obvious evidence for a relationship between $T$. caerulescens plant $\mathrm{Cd}$ content or accumulation and growth (Escarré et al., 2000; Molitor et al., 2005). Roosens et al. (2003) have, however, found a positive relationship between plant biomass and $\mathrm{Cd}$ content in solution and in dry biomass for two French populations. In our study, the populations with higher Cd hyperaccumulation capacity had more and bigger leaves. Nothing is known about the effects of soil Cd concentration and Cd hyperaccumulation on reproductive traits. In our study, the reproductive traits were not correlated with Cd concentrations in soils. Nevertheless, our populations with a greater $C d$ hyperaccumulation capacity had more fruits and heavier seeds per plant, and could potentially produce more viable offspring. No differences in the shoot and reproductive quality between low and high Cd hyperaccumulation capacity populations, or potentially a lower shoot and reproductive quality, for the populations with a higher Cd hyperaccumulation capacity, would be expected when considering the drought, interference, and defence hypotheses. Indeed, there was no reason to expect lower shoot and reproductive quality for the low Cd hyperaccumulating populations compared to the high ones from any of these three hypotheses. In addition, note that, in the present study, the influence of environmental parameters, such as solar radiation and wetness index (drought hypothesis), and the populations density (interference hypothesis) on the population shoot and reproductive traits, were controlled. Jiang et al. (2005) con- cluded that Cd hyperaccumulation deters thrips from feeding on T. caerulescens leaves, but they suggested that this protective role could also be considered as a consequence of $\mathrm{Cd}$ hyperaccumulation. They proposed that, in some populations, the Cd hyperaccumulation system may also be an inadvertent result of selection for the acquisition of other nutrients, such as Fe (Lombi et al., 2002; Roosens et al., 2003). The results of our study sustain the tolerance/disposal hypothesis proposed by Boyd and Martens (1992). The hyperaccumulation and sequestration of $\mathrm{Cd}$ in the leaves of $T$. caerulescens could lead to a depletion of $\mathrm{Cd}$ in the soil (correlation between $\mathrm{HNO}_{3}$ extractable $\mathrm{Cd}$ concentration in soils and $\mathrm{Cd}$ concentration in plants) and increase the supply of nutrients (e.g., $\mathrm{Zn}, \mathrm{Fe}, \mathrm{Cu}$ ) for uptake (less competition between $\mathrm{Cd}$ and nutriments). Cadmium hyperaccumulation could, therefore, induce a better nutrient uptake (and transfer) and would thus lead to more shoot, fruits material, and heavier seeds, as seen in this study. In T. caerulescens, $\mathrm{Cd}$ accumulation and tolerance were found to be correlated (Escarré et al., 2000). Lombi et al. (2000) and Roosens et al. (2003) observed high degrees of both Cd tolerance and hyperaccumulation in populations from Southern France (highly hyperaccumulating ecotype) and these two mechanisms still remain difficult to dissociate (Cosio, 2004). Indeed, Lombi et al. (2000) proposed that Cd hypertolerance and Cd hyperaccumulation were somehow linked.

In summary, we showed that, in the studied populations: 1) the Cd concentration in $T$. caerulescens plants depended principally on the $\mathrm{HNO}_{3}$ extractable $\mathrm{Cd}$ concentration in soils, 2) the $\mathrm{Cd}$ concentration in plants was positively correlated to plant $\mathrm{Zn}$, $\mathrm{Fe}$, and $\mathrm{Cu}$ concentrations, and that 3 ) the populations with a high Cd hyperaccumulation capacity had better growth and reproduction. Our results support the tolerance/disposal hypothesis and indicate that Cd hyperaccumulation could be a 


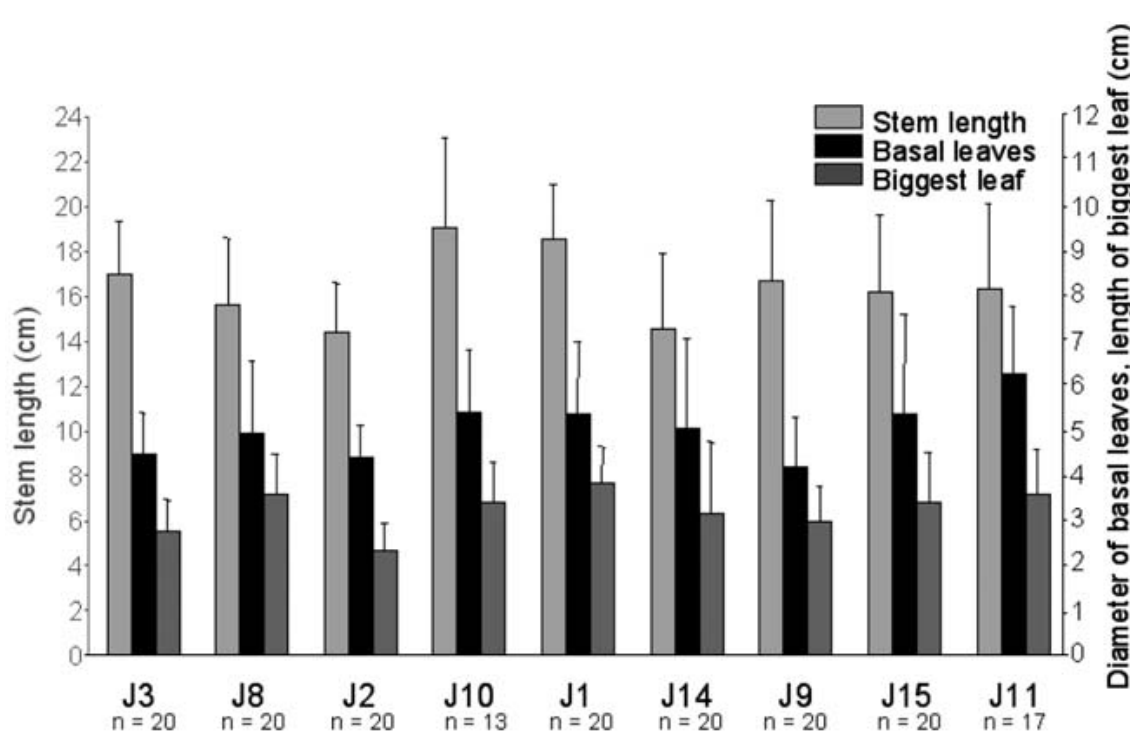

A

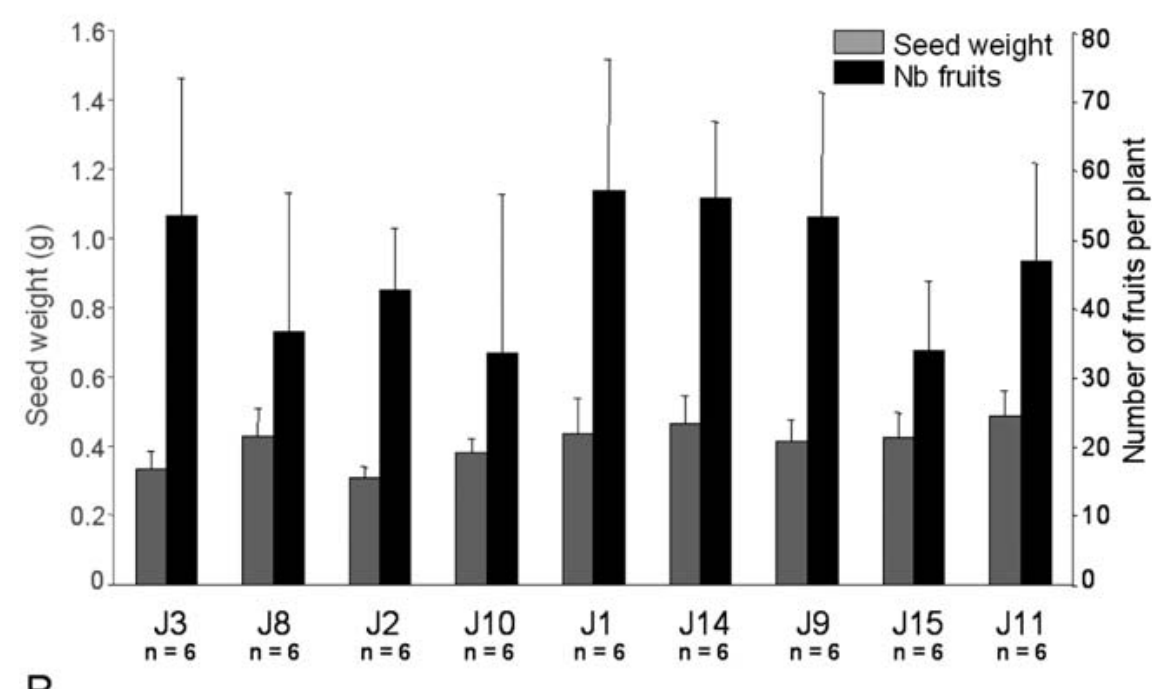

Fig. 3 Mean and standard deviation of the stem length (in $\mathrm{cm}$ ), diameter of the basal leaves (in $\mathrm{cm}$ ), length of the biggest leaf per individual (in $\mathrm{cm})(\mathbf{A})$, and number of fruits per plant and seed weights (in g) (B) per population, sorted by their Cd hyperaccumulation capacity. $\mathrm{n}$ is the number of plant samples recorded by population.

B

mechanism for increased $\mathrm{Cd}$ tolerance. The relationship between the higher vegetative and reproductive output and $\mathrm{Cd}$ hyperaccumulation capacity remains to be verified using an experimental approach on the nine studied populations under controlled conditions.

\section{Acknowledgements}

The authors thank D. Hammer for helpful discussion and correction of the manuscript, M. S. Diallo and C. Cosio for help in soil and plant analyses, D. Perret for ICP-AES measurements, N. Meisser for his geological advice, and E. Samaritani and J. Félix for help in the fieldwork.

\section{References}

Antonovics, J., Bradshaw, A. D., and Turner, R. G. (1971) Heavy metal tolerance in plants. Advances in Ecological Research 7,1-85.

Assunção, A. G. L., Bokum, W. M., Nelissen, H. J. M., Vooijs, R., Schat, H., and Ernst, W. H. O. (2003) Differential metal-specific tolerance and accumulation patterns among Thlaspi caerulescens populations originating from different soil types. New Phytologist 159 , $411-419$.

Atteia, O., Thélin, Ph., Pfeifer, H. R., Dubois, J. P., and Hunziker, J. C. (1995) A search for the origin of cadmium in the soil of Swiss Jura. Geoderma 68, 149-172.

Baker, A. J. M. (1981) Accumulators and excluders - strategies in the response of plants to heavy metals. Journal of Plant Nutrition 3, $643-654$.

Baker, A. J. M. and Brooks, R. R. (1989) Terrestrial higher plants which hyperaccumulate metallic elements - a review of their distribution, ecology and phytochemistry. Biorecovery 1, 81-126. 
Baker, A. J. M., Reeves, R. D., and Hajar, A. S. M. (1994) Heavy metal accumulation and tolerance in British populations of metallophyte Thlaspi caerulescens J. and C. Presl (Brassicaceae). New Phytologist 127, $61-68$.

Baker, A. J. M. and Walker, P. L. (1989) Ecophysiology of metal uptake by tolerant plants. In Heavy Metal Tolerance in Plants: Evolutionary Aspects (Shaw, A. J., ed.), Boca Raton, FL, USA: CRC Press, pp. $155-177$.

Benitez, N. (1999) Cadmium speciation and phyto-availability in soils of the Swiss Jura: hypothesis about its dynamics. PhD thesis, EPFL, Switzerland, No. 2066.

Blaylock, M. J. and Huang, J. W. (2000) Phytoextraction of metals. In Phytoremediation of Toxic Metals: Using Plants to Clean Up the Environment (Raskin, I. and Ensley, B. D., eds.), John Wiley and Sons Inc., pp. $53-70$.

Boyd, R. S. (2004) Ecology of metal hyperaccumulation. New Phytologist 162, 563- 567 .

Boyd, R. S. and Jaffré, T. (2002) Phytoenrichment of soil Ni content by Sebertia acuminata in New Caledonia and the concept of elemental allelopathy. South African Journal of Science 97, 535-538.

Boyd, R. S. and Martens, S. N. (1992) The raison d'etre for metal hyperaccumulation by plants. In The Vegetation of Ultramafic (Serpentine) Soils (Baker, A. J. M., Proctor, J., and Reeves, R. D., eds.), Andover, GB: Intercept, pp. 279-289.

Brooks, R. R. (1998) General introduction. In Plants that Hyperaccumulate Heavy Metals (Brooks, R. R., ed.), Cambridge: CAB International.

Brown, S., Chaney, R., Angle, J., and Baker, A. (1994) Phytoremediation potential of Thlaspi caerulescens and bladder campion for zinc- and cadmium-contamined soil. Journal of Environmental Quality 23, $1151-1157$.

Chaney, R. L. (1983) Plant uptake of inorganic waste constituents. In Land Treatment of Hazardous Waste (Parr, J. F., Marsh, P. B., and Kla, J. S., eds.), Park Ridge, NJ: Noyes Data Corp., pp.50-76.

Cosio, C. (2004) Phytoextraction of heavy metal by hyperaccumulating and non hyperaccumulating plants: comparison of cadmium uptake and storage mechanisms in the plants. PhD thesis, ENAC, EPFL, Switzerland, No. 2937.

Cosio, C., Martinoia, E., and Keller, C. (2004) Hyperaccumulation of cadmium and zinc in Thlaspi caerulescens and Arabidopsis halleri at the leaf cellular level. Plant Physiology 134, 716-725.

Escarré, J., Lefèbvre, C., Gruber, W., Leblanc, M., Lepart, J., Rivière, Y., and Delay, B. (2000) Zinc and cadmium hyperaccumulation by Thlaspi caerulescens J. et C. Presl. from metalliferous and nonmetalliferous sites in the Mediterranean area: implications for phyto-remediation. New Phytologist 145, 429-437.

Evangelou, M. W. H., Daghan, H., and Schaeffer, A. (2004) The influence of humic acids on the phytoextraction of cadmium from soil. Chemosphere 57, 207-213.

FAC (Eidgenössische Forschungsanstalt für Agrikulturchemie und Umwelthygiene) (1989) Methoden für die Bodenuntersuchungen. Bern-Liebefeld, Switzerland: Schriftenreihe der FAC 5.

FAL (Eidgenössische Forschungsanstalt für Agrarökologie und Landbau) (1998) Manuel pour l'analyse des sols, des plantes et de l'eau de percolation lysimétrique. Zürich-Reckenholz, Switzerland: Les Cahiers de la FAL 27.

Ihaka, R. and Gentleman, R. (1996) R: A language for data analysis and graphics. Journal of Computational and Graphical Statistics 5, $299-314$.

Jiang, R. F., Ma, D. Y., Zhao, F. J., and McGrath, S. P. (2005) Cadmium hyperaccumulation protects Thlaspi caerulescens from leaf feeding damage by thrips (Frankliniella occidentalis). New Phytologist 167, $805-814$.

Keller, C., Hammer, D., Kayser, H., Richner, W., Brodbeck, M., and Sennhauser, M. (2003) Root development and heavy metal phytoextraction efficiency: comparaison of different plant species in the field. Plant and Soil 249, 67-81.
Liebig, T. and Dubois, J.-P. (1997) Speciation and bioavailability of some soils of the Swiss Jura. In Extended Abstracts of the 4th International Conference on the Biochemistry of Trace Elements, Berkeley, CA, 23 - 26 June 1997, pp.111 - 112.

Lombi, E., Tearall, K. L., Howarth, J. R., Zhao, F. J., Hawkesford, M. J., and McGrath, S. P. (2002) Influence of iron status on cadmium and zinc uptake by different ecotypes of the hyperaccumulator Thlaspi caerulescens. Plant Physiology 128, 1359-1367.

Lombi, E., Zhao, F. J., Dunham, S. J., and McGrath, S. P. (2000) Cadmium accumulation in populations of Thlaspi caerulescens and Thlaspi goesingense. New Phytologist 145, 11-20.

Lombi, E., Zhao, F. J., McGrath, S. P., Young, S. D., and Sacchi, G. A. (2001) Physiological evidence for a high-affinity cadmium transporter highly expressed in a Thlaspi caerulescens ecotype. New Phytologist 149, 53-60.

Marschner, H. (1995) Mineral Nutrition of Higher Plants. New York: Academic Press, Hartcourt Brace and Company.

Meerts, P. and Van Isacker, N. (1997) Heavy metal tolerance and accumulation in metallicolous and non-metallicolous populations of Thlaspi caerulescens from continental Europe. Plant Ecology 133, $221-231$.

Molitor, M., Dechamps, C., Gruber, W., and Meerts, P. (2005) Thlaspi caerulescens on nonmetalliferous soil in Luxembourg: ecological niche and genetic variation in mineral element composition. New Phytologist 165, 503-512.

Noret, N., Meerts, P., Tolra, R., Poschenrieder, C., Barcelo, J., and Escarre, J. (2005) Palatability of Thlaspi caerulescens for snails: influence of zinc and glucosinolates. New Phytologist 165, 763-772.

OIS (1998) Swiss Ordinance Relating to Impacts on the Soils. Switzerland, 1st July 1998, SR 814.12.

Pollard, A., Powell, K., Harper, F., and Smith, J. (2002) The genetic basis of metal hyperaccumulation in plants. Critical Reviews in Plant Sciences 21, 539-566.

Shaw, B. P., Sahu, S. K., and Mishra, R. K. (2004) Heavy metal induced oxidative damage in terrestrial plants. In Heavy Metal Stress in Plants (Prasad, M. N. V., ed.), Berlin, Heidelberg: Springer, pp. 84 126.

Reeves, R. D. and Brooks, R. R. (1983) European species of Thlaspi L. (Cruciferae) as indicators of nickel and zinc. Journal of Geochemical Exploration 18, 275-283.

Roosens, N., Verbruggen, N., Meerts, P., Ximénez-Embún, P., and Smith, J. A. C. (2003) Natural variation in cadmium tolerance and its relationship to metal hyperaccumulation for seven populations of Thlaspi caerulescens from western Europe. Plant, Cell and Environment 26, 1657-1672.

Sanita di Toppi, L. and Gabbrielli, R. (1999) Response to cadmium in higher plants. Environmental and Experimental Botany 41, 105 130.

Severne, B. C. (1974) Nickel accumulation by Hybanthus floribundus. Nature 248, 807-808.

Vert, G., Grotz, N., Dedaldechamp, F., Gaymard, F., Guerinot, M. L., Briata, J. F., and Curie, C. (2002) IRT1, an Arabidopsis transporter essential for iron uptake from the soil for plant growth. Plant Cell 14, $1223-1233$.

Welch, R. M. and Norvell, W. A. (1999) Mechanisms of cadmium uptake, translocation and deposition in plants. In Cadmium in Soils and Plants (McLaughlin, M. J. and Singh, A., eds.), Dordrecht, The Netherlands: Kluwer Academic Publishers, pp.125 - 150.

Welten, M. and Sutter, H. C. R. (1982) Atlas de la Distribution des Ptéridophytes et des Phanérogames de la Suisse, Vol.1. Basel: Birkhäuser Verlag.

Whiting, S. N., Neumann, P. M., and Baker, A. J. M. (2003) Nickel and zinc hyperaccumulation by Alyssum murale and Thlaspi caerulescens (Brassicaceae) do not enhance survival and whole-plant growth under drought stress. Plant, Cell and Environment 26, $351-360$. 
Wilson, J. B. and Agnew, A. D. Q. (1992) Positive-feedback switches in plant communities. Advances in Ecological Research 23, 263-336.

Zha, H. G., Jiang, R. F., Zhao, F. J., Vooijs, R., Schat, H., Barker, J. H. A., and McGrath, S. P. (2004) Co-segregation analysis of cadmium and zinc accumulation in Thlaspi caerulescens interecotypic crosses. New Phytologist 163, 299-312.

Zhao, F. J., Lombi, E., and McGrath, S. P. (2003) Assessing the potential for zinc and cadmium phytoremediation with the hyperaccumulator Thlaspi caerulescens. Plant and Soil 249, 37-43.

Zimmermann, N. E. and Kienast, F. (1999) Predictive mapping of alpine grasslands in Switzerland: Species versus community approach. Journal of Vegetation Science 10, 469-482.

\section{N. Basic}

Department of Ecology and Evolution University of Lausanne

Biology Building

1015 Lausanne

Switzerland

E-mail: nevena.basic@unil.ch

Editor: H. de Kroon 